\title{
Detection of CD5 in B-cell chronic lymphoproliferative diseases by flow cytometry: a strong expression in B-cell chronic lymphocytic leukemia
}

\author{
Geraldo Barroso Cavalcanti Júnior², Valeria Soraya de Farias Sales², Dany Geraldo Kramer Cavalcanti e Silva², \\ Maria Cleide de Araújo Lopes ${ }^{4}$, Aldair de Souza Paiva ${ }^{5}$, Henrique Eduardo Macedo da Fonseca ${ }^{5}$, \\ Francisco Fernandes do Nascimento Júnior ${ }^{5}$, Maria Zélia Fernandes ${ }^{5}$
}

Cavalcanti Júnior GB, Sales VSF, Silva DGKC, Lopes MCA, Paiva AS, Fonseca HEM, Nascimento Júnior FF, Fernandes MZ. Detection of CD5 in B-cell chronic lymphoproliferative diseases by flow cytometry: a strong expression in B-cell chronic lymphocytic leukemia. Acta Cir Bras [serial on line] Available from: URL: htt://www.scielo.br/acb.

\begin{abstract}
Purpose: CD5 is a T cell marker, aberrantly express in B cell chronic lymphocytic leukemia (B-CLL) and mantle cell lymphoma (MCL). Other chronic B cell malignancies including hairy cell leukemia (HCL) and B cell prolymphocytic leukemia (B-PLL) are CD5 negative or express this antigen in a weak way. In this study, CD5 expression was investigated in leukemic cells from 42 patients with chronic B cell lymphoproliferative disease. Methods: We studied the CD5 expression in leukemic cells from 42 patients with chronic B-cell malignancies by flow cytometry. Demographic features such as age, sex and clinical date were also analyzed. Results: There were 22 males and 20 females. The immunophenotyping showed that 35 cases were B-CLL, 3 B-PLL and HCL and one patient was MCL. CD5 expression was present in all B-CLL and MCL. Low expression of CD5 was observed in one patient with BPLL and negative in all cases of HCL. Conclusion: Our date demonstrated that CD5 expression can help distinguish among B-CLL from HCL and B-PLL, but is similar expressed in MCL.
\end{abstract}

KEYWORDS: CD5. B cell. Chronic lymphocytic leukemia. B-cell prolymphocytic leukemia. Hairy cell. Mantle cell lymphoma.

\section{Introduction}

CD5 is a T-cell marker that also is expressed in B1 subset of human B lymphocytes. Mature B cell malignancies, such as B-cell chronic lymphocytic leukemia (B-CLL) and mantle cell lymphoma (MCL) are mostly CD5+. Other B cell chronic lymphoproliferative disorders such as B cell prolymphocytic leukemia (B-PLL) and hairy cell leukemia (HCL) are CD5 negative or expressed low level of this antigen ${ }_{1,3}$.

This immunological characteristic of B-CLL and MCL is an important parameter to distinct between these entities and other chronic B-cell lymphoproliferative diseases such as B-PLL and $\mathrm{HCL}^{4}$.

Although the biologic function of CD5 is unknown, it is believed that in $\mathrm{T}$ cell subsets this antigen is an important molecule in the mechanism of cellular activation. In B1 lymphocytes or resting cells, it has also suggested that CD5+ $\mathrm{B}$-cell may have a role in autoimmunity. They are increased in some people with autoimmune diseases secreting immunoglobulin that reacts with autoantigens such as rheumatoid factor and single and double-stranded DNA $(1,5)$. Some reports have suggested an association between B-CLL CD5+ and autoimmune disorders ${ }^{1,4}$.
The objective of this study was designed to evaluate the diagnostic value of CD5 expression in leukemic cells from peripheral blood of 42 patients with B-cell chronic lymphoproliferative diseases.

\section{Methods}

\section{Samples of Patients}

Peripheral blood from 42 patients with chronic lymphoproliferative disease (CLD) diagnosted at the Instituto de Onco-Hematologia de Natal (IOHN) were studied. Informed consent was provided by all participants and they study was done with in the guiderlines of the Declaration of Helsinki. Blood samples were collected in tubes containing EDTA.

We also evaluated clinical and hematological date at diagnosis and the patients were grouped as male vs female, age and clinical features.

All cases of CLD were analyzed and classified when possible according to standard cytomorpholologic and immunophenotypic criteria ${ }^{4,6,12}$.

\footnotetext{
1. Article from Departamento de Análises Clínicas e Toxicológicas da Universidade Federal do Rio Grande do Norte, Natal, RN, Brazil and Instituto de Onco-Hematologia de Natal.

2. Professor, Doctor, Departamento de Análises Clínicas e Toxicológicas and Programa de Pós-Graduação em Ciências da Saúde da Universidade Federal do Rio Grande do Norte, Natal, RN, Brazil.

3. Trainee, Departamento de Análises Clínicas e Toxicológicas da Universidade Federal do Rio Grande do Norte, Natal, RN, Brazil.

4. Biochemistry, Instituto de Onco Hematologia de Natal, Natal RN, Brazil.

5. Medical Doctor, Instituto de Onco Hematologia de Natal, Natal RN, Brazil.
} 


\section{Hematological analysis}

Ten milliliters ( $\mathrm{mL}$ ) of peripheral venous blood was collected into vacutainer tubes containing EDTA and mixed immediately. The white blood cells count (WBC), hemoglobin dosage and platelet count was accomplished in the hematological analyzer (Cell-Dyn 3000). The cytomorphologic analysis was accomplished in blood films stained by Leishmann. There were counted 100 leukocytes and the result scored in percentage. Cytomorphologic alterations were written down properly in the record of results.

\section{Flow cytometry analyzis}

The Immunophenotyping was performed by only and dualcolor flow-cytometry analysis of peripheral blood samples. Surface markers were identified by using monoclonal antibodies (MoAb) against CD3, CD10, CD19, CD45, CD14, CD16/56, CD8, CD5, CD7, CD22, CD23, CD25, CD38, HLADR, anti immunoglobulin heavy chain ( $\mathrm{IgH})$, kappa (?) and lambda (?) light chains of immunoglobulin. All MoAb were purchased from Becton-Dickinson Immunocytochemistry System (San Jose, CA).

One hundred microliliters (100 ?L) of total blood cells previously homogenized, were incubated with the 20 ?L of $\mathrm{MoAb}$ for 30 minutes at room temperature and in darkness. Then, the suspension was homogenized and increased to the same $1 \mathrm{ml}$ of a 1 in 10 dilution of Becton Dickinson's FACS lysing solution in destilled water, having new incubation for more 10 minutes in the room temperature. After this period, the cellular suspension was centrifuged by 5 minutes at 1500 rpm, the supernadant fluid discarded and the cell pellet was ressuspended in cold phosphate buffered saline (PBS, $\mathrm{pH}$ 7.2) and centrifuged again at $1.500 \mathrm{rpm}$, being this last stage accomplished twice again. At last, the cell pellet was resuspended in $1 \mathrm{~mL}$ of cold $1 \%$ of paraformaldehyde in PBS and the cell suspensions were kept on the dark in cold until flow cytometric analysis.

The samples were analysed in Fluorescence Activated Cell Analyser (FACScan, San Jose, CA, USA) with Cell Quest software. The (Cell Quest ${ }^{\mathrm{TM}}$ Software, Becton Dickinson Immunocytometry Systems, San Jose, CA, USA), with acquisition of 10.000 events, being taken into account the parameters Forward Scatter (FSC) in lineal scale that evaluates the cellular size, Side Scatter (SSC) also in lineal scale, which evaluates the cellular complexity, FL1 and FL2 in logaritimical scale detect green and orange fluorescence, respctively which represents the reaction antigen-antibody conjugated fluorescein isohtiocyanate (FICT), phycoerythrin (PE).

The immunophenotyping was considered positive there were happened more than $25 \%$ of positive cells for all MoAb. The Results were supplied in the form of histograms in percentage of the cellular population with positive or negative reaction and fluorescence intensity.

\section{Results}

\section{Patients Characteristics}

The clinical and demographic characteristics of all patients analyzed in this study were showed in table I. There were 22 males and 20 females and due to the small number of cases, no statistical significance was observed. The WBC was longer when compared with other B-cell malignancies. The lymphadenopaty was the most frequent clinical finding in all diseases, observed in $75 \%$ of B-CLL patients and in all cases of B-PLL, HCL and MCL.

Cytomorphologic alteractions of leucocytes from peripheral blood were also observed in blood film stained. In B-PLL, were observed elevated count of pro-lymphocytes in all cases ( $355 \%$ ) and in HCL was observed the presence of lymphocytes with cytoplasmatic projections (hairy cells).
TABLE 1 - Patients characteristic of the subjects

\begin{tabular}{l|c|c|c|c}
\hline \hline & $\begin{array}{c}\text { CLL } \\
\left(\mathbf{n}^{\mathbf{0}}=\mathbf{3 5}\right)\end{array}$ & $\begin{array}{c}\text { PLL } \\
\left(\mathbf{n}^{\mathbf{0}}=\mathbf{3}\right)\end{array}$ & $\begin{array}{c}\text { HCL } \\
\left(\mathbf{n}^{\mathbf{0}}=\mathbf{3}\right)\end{array}$ & $\begin{array}{c}\text { MCL } \\
\left(\mathbf{n}^{\mathbf{0}}=\mathbf{1}\right)\end{array}$ \\
\cline { 2 - 5 } & Min-Max (me) & Min-Max (me) & Min-Max (me) & Min-Max \\
\hline Age & $48-81(69)$ & $66-92(77)$ & $52-73(62)$ & 82 \\
\hline Males & $\mathbf{n}^{\mathbf{0}} / \mathbf{( \% )}$ & $\mathbf{n}^{\mathbf{0}} / \mathbf{( \% )}$ & $\mathbf{n}^{\mathbf{0}} /(\mathbf{\%})$ & $\mathbf{n}^{\mathbf{0}} / \mathbf{( \% )}$ \\
Females & $17(48.6)$ & $3(100)$ & $1(33,3)$ & $1(100)$ \\
Lymphadenopathy & $18(51.4)$ & $0(-)$ & $2(66.7)$ & $0(-)$ \\
Splenomegaly & $25(71.4)$ & $3(100)$ & $2(66.7)$ & $1(100)$ \\
Anemie & $24(68.6)$ & $3(100)$ & $3(100)$ & $0(-)$ \\
Hepatomegaly & $19(54.3)$ & $3(100)$ & $2(66.7)$ & $0(-)$ \\
& $16(47.5)$ & $3(100)$ & $1(33.3)$ & $0(-)$ \\
\hline WBC / PB.(x10 $\left.{ }^{3}\right)$ & $7.8-334.0(90.5)$ & $16.2-125.0(17.9)$ & $22.2-22.9(22.2)$ & 77.5 \\
Lymphocytes /PB (\%) & $70-96(81)$ & $60-81(61)^{*}$ & $60-94(69)$ & 80 \\
Granulocytes (\%) & $04-40(20($ & $15-40(39)$ & $06-39(31)$ & 29 \\
HB (g/dL) & $6.6-15.0(12,7)$ & $6.8-16,0(8.0)$ & $11.7-13.6(13.0)$ & 9.8 \\
Platelet /PB (x10 $\left.{ }^{3}\right)$ & $82-253.0(170.0$ & $46-328.0(106)$ & $180-537.0(188.0)$ & 150.0 \\
\hline \hline
\end{tabular}

B-CLL ( B-cell chronic lymphocytic leukemia); PLL (prolymphocytic leukemia); HCL (hairy cell leukemia ); MCL (mantle cell lymphoma); Min (minimal); Max (maximum); Med (mediam); $n^{\circ}$ (number of cases); PB (peripheral blood); WBC (White Blood Cells); HB (hemoglobin dosage); $(*)$ prolymphocytes count more than $55 \%$ 
TABLE 2 - Immunophenotypic characteristic of 42 cases of B-cell lymphoproliferative diseases

\begin{tabular}{l|c|c|c|c}
\hline & $\begin{array}{c}\mathbf{C L L} \\
\mathbf{n}^{\mathbf{0}}=\mathbf{3 5}\end{array}$ & $\begin{array}{c}\mathbf{L P L} \\
\mathbf{n}^{\mathbf{0}}=\mathbf{0 3}\end{array}$ & $\begin{array}{c}\mathbf{H C L} \\
\mathbf{n}^{\mathbf{0}}=\mathbf{0 3}\end{array}$ & $\begin{array}{c}\mathbf{L C M} \\
\mathbf{n}^{\mathbf{0}}=\mathbf{0 1}\end{array}$ \\
\cline { 2 - 5 } $\mathbf{n}^{\mathbf{0}} \mathbf{a} / \mathbf{n}^{\mathbf{0}}+$ & $\mathbf{n}^{\mathbf{0}} \mathbf{a} / \mathbf{n}^{\mathbf{0}}+$ & $\mathbf{n}^{\mathbf{0}} \mathbf{a} / \mathbf{n}^{\mathbf{0}+}$ & $\mathbf{n}^{\mathbf{0}} \mathbf{a} / \mathbf{n}^{\mathbf{0}}+$ \\
\hline $\mathbf{C D 3}$ & $35 / 00$ & $03 / 00$ & $03 / 00$ & $01 / 00$ \\
\hline CD4 & $35 / 00$ & $03 / 00$ & $03 / 00$ & $01 / 00$ \\
\hline CD7 & $35 / 35^{* *}$ & $03 / 01^{*}$ & $00 / 00$ & $01 / 01^{* *}$ \\
\hline CD8 & $35 / 00$ & $03 / 00$ & $03 / 00$ & $01 / 00$ \\
\hline CD10 & $35 / 00$ & $03 / 00$ & $03 / 00$ & $01 / 00$ \\
\hline CD14 & $35 / 00$ & $03 / 00$ & $03 / 00$ & $01 / 00$ \\
\hline CD16/56 & $35 / 00$ & $03 / 00$ & $03 / 00$ & $01 / 00$ \\
\hline CD19 & $35 / 00$ & $03 / 00$ & $03 / 00$ & $01 / 00$ \\
\hline CD22 & $35 / 35$ & $03 / 03$ & $03 / 03$ & $01 / 01$ \\
\hline CD25 & $35 / 35$ & $03 / 03$ & $03 / 03$ & $01 / 01$ \\
\hline CD38 & $35 / 35$ & $03 / 03$ & $03 / 03$ & $01 / 01$ \\
\hline CD45 & $35 / 00$ & $03 / 00$ & $03 / 03$ & $01 / 01$ \\
\hline IgH & $35 / 00$ & $03 / 00$ & $03 / 03$ & $01 / 01$ \\
\hline$\square$ & $35 / 35$ & $03 / 03$ & $03 / 03$ & $01 / 01$ \\
\hline$\square$ & $35 / 35^{*}$ & $03 / 03^{* *}$ & $03 / 03^{* *}$ & $01 / 01 * *$ \\
\hline HLADR & $35 / 32^{*}$ & $03 / 03^{* *}$ & $03 / 02^{* *}$ & $01 / 01^{* *}$ \\
\hline & $35 / 03^{*}$ & $03 / 03^{* *}$ & $03 / 01^{* *}$ & $01 / 00^{* *}$ \\
\hline
\end{tabular}

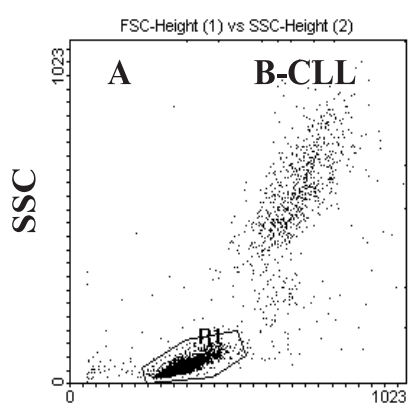

FSC

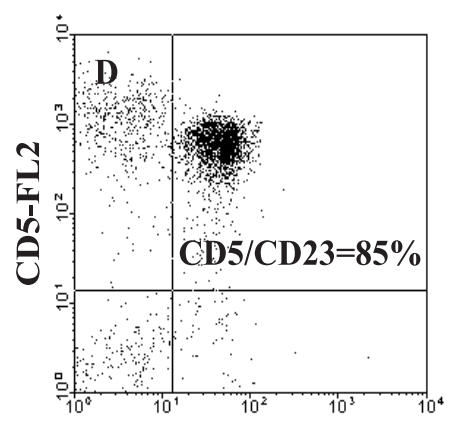

CD23-FL1
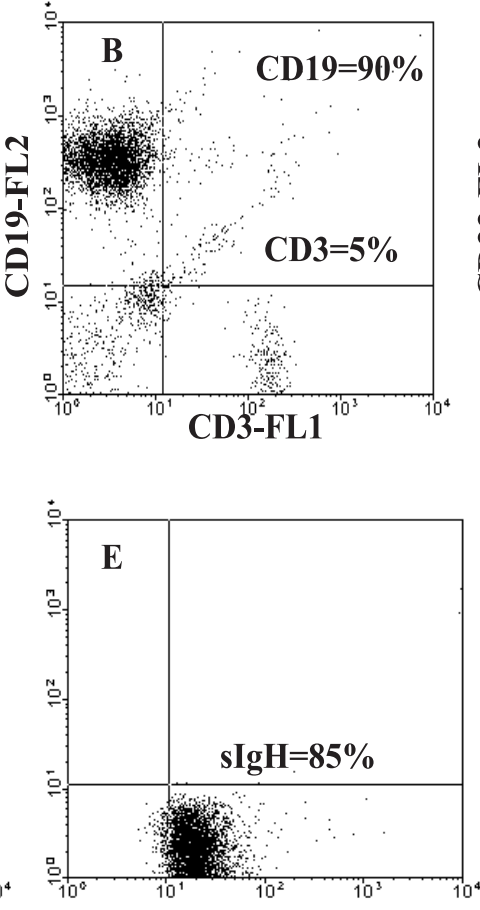

sIgH-FL1
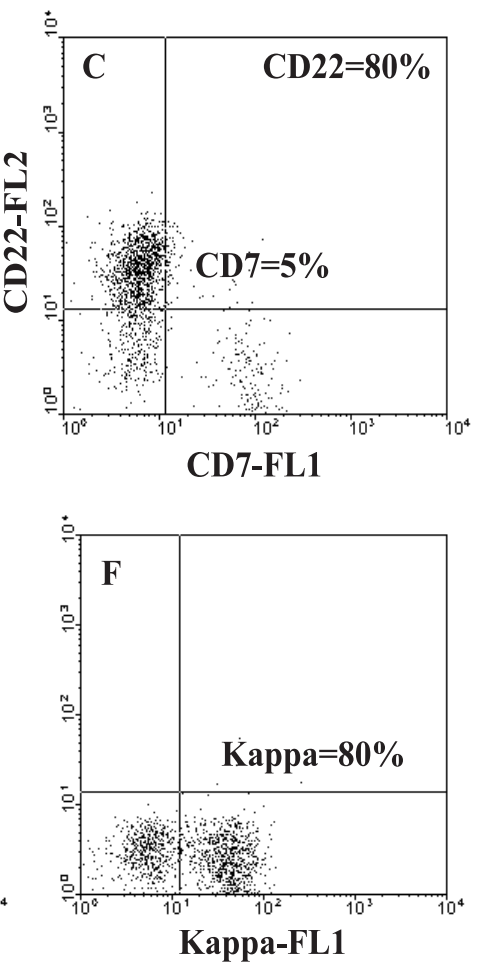

B-CLL (B-cell chronic lymphocytic leukemia); PLL (prolymphocytic leukemia); HCL (hairy cell leukemia ); MCL (mantle cell lymphoma; (*) low expression; (**) strong expression; ?? (kappa light chain of immunoglobulins); ?? (lambda light chain of immunoglobulins); IgH (heavy chain of immunoglobulins); $\mathrm{n}^{\circ} \mathrm{a}$ (number of cases analyzed); $\mathrm{n}+$ (number of positives cases)

\section{FIGURE 1 -}

Immunophenotyping characteristic of one patient with B-cell chronic lymphocytic Leukemia. A) SSC and FSC characteristic of leukemic cells analyzed; B) expression of CD19 and lack of CD3; C) weak expression of CD22 and lack expression of CD7; D) strong expression of CD5 and CD23; E) low expression of surface heavy chain of immunoglobulins; F) low expression of kappa light chain of immunoglobulins 

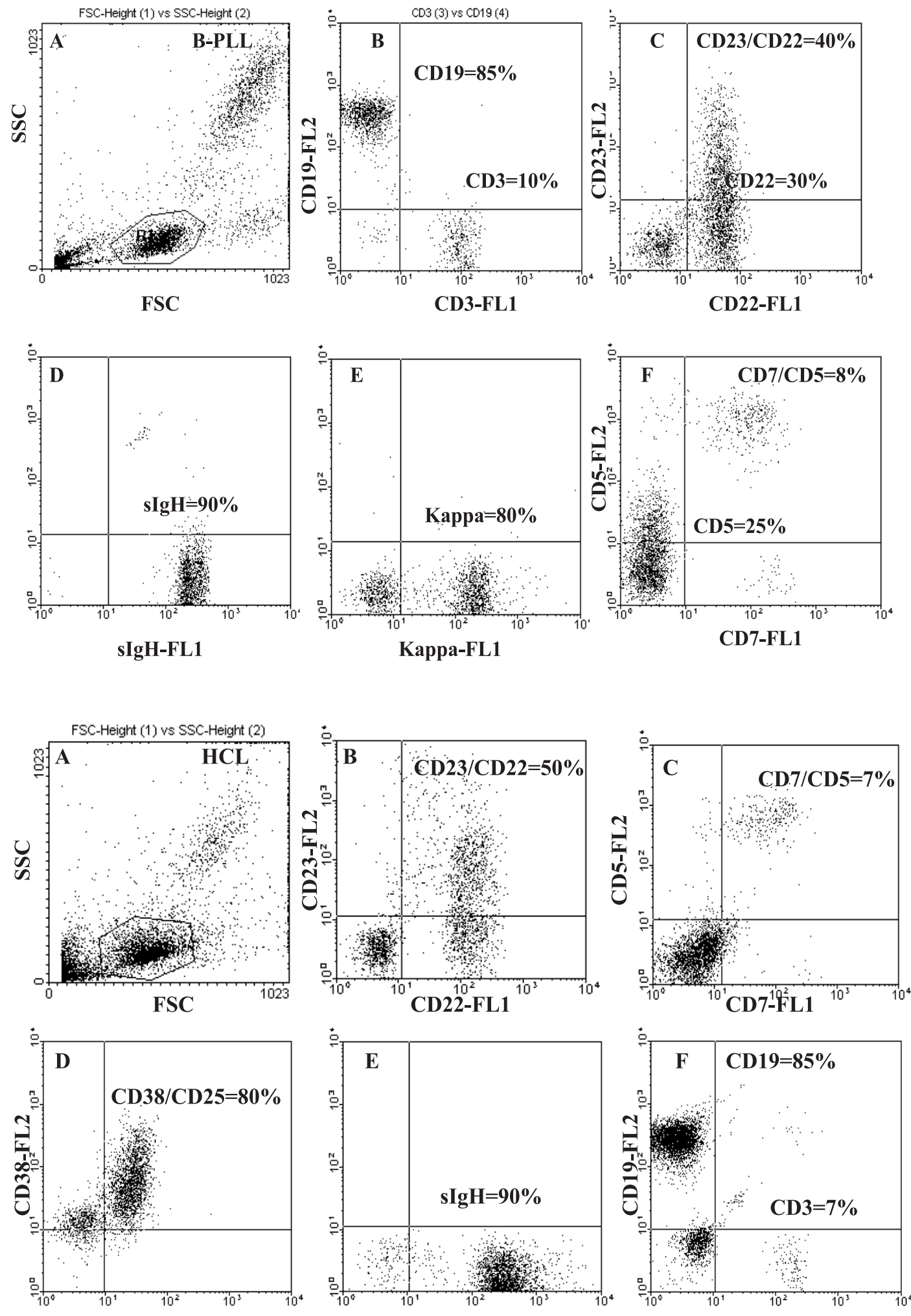

CD25-FL1

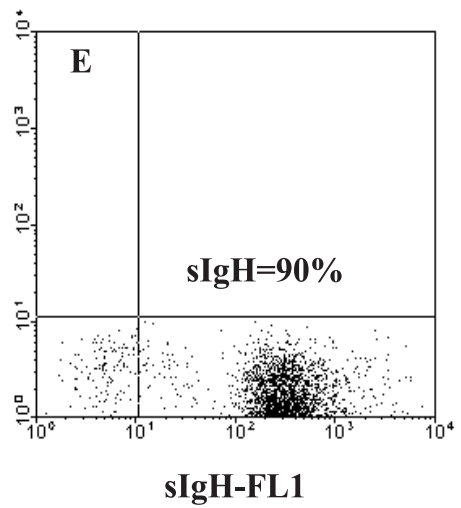

sIgH-FL1

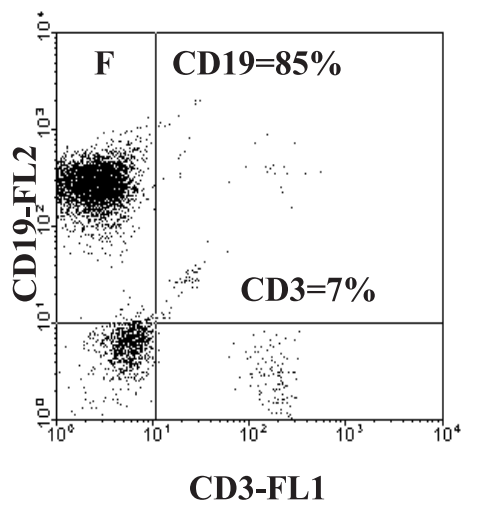

FIGURE 2 -

Immunophenotyping characteristic of one patient with B-cell prolymphocytic leukemia

A) SSC and FSC characteristic of leukemic cells analyzed; B) expression of CD19 and lack of CD3; C) coexpression of CD22 and CD23; D) strong expression surface heavy chain of immunoglobulins; E) strong expression of kappa light chain of immunoglobulins.; F) low expression of CD5 and lack of CD7
FIGURE 3 -

Immunophenotyping characteristic of one patient with hairy cell leukemia

A) SSC and FSC characteristic of leukemic cells analyzed; B) coexpression of CD22 and CD23; C) lack of expression of CD7 and CD5 antigens; D) coexpression of CD25 and CD38; E) strong expression of heavy chain of immunoglobulins; F) expression of CD19 and lack of CD3 


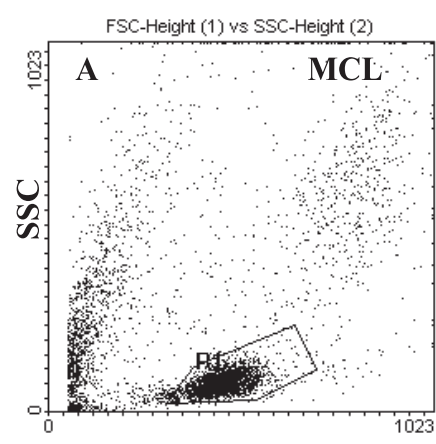

FSC

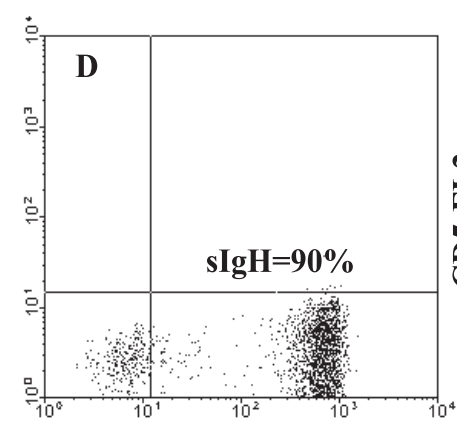

SIgH-FL1

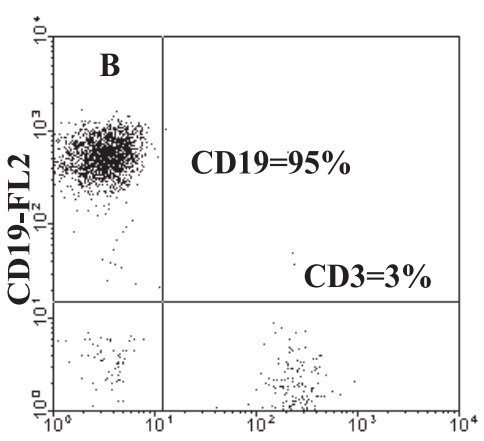

CD3-FL1

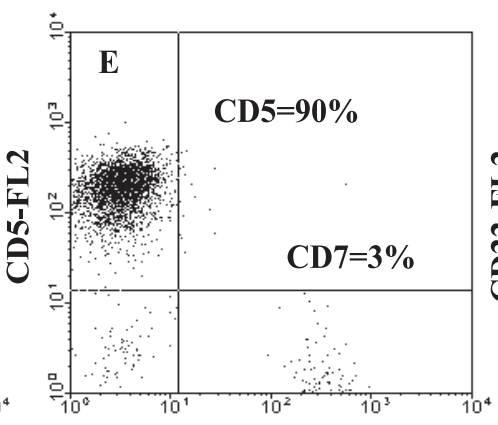

CD7-FL1
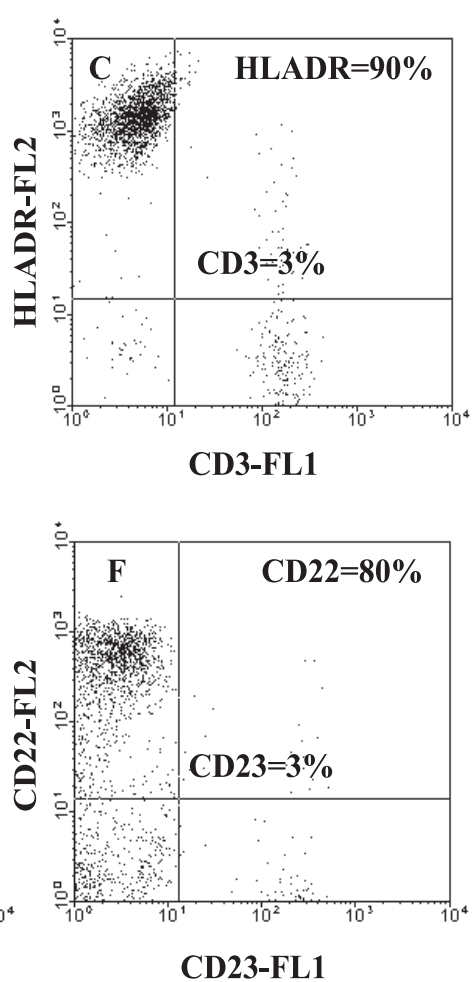

FIGURE 4-Leukemic cells from MCL patient were characterized by strong expression of CD5, sIg and CD22 and lack of CD23

\section{Immunophenotyping}

There were 35 cases of B-CLL and 7 non B-CLL. Of the latter, 3 cases were classified as HCL, 3 were B-PLL and one case was MCL. In all studied leukemic cells expressed B cell antigen like CD19, CD22 and surface immunoglobulin (sIg) with clonal restriction, associated with strong expression of HLADR and absence of natural killer (NK) and T cell antigens, such as CD16/56, CD3, CD7, CD4 and CD8 (Table II). Leukemic cells from B-CLL patients, were characterized by strong coexpression of CD23 and CD5, associated with low expression of sIg and CD22 in all cases (Figure 1). In B-PLL, we observed that leukemic cells exhibited high level of sIg and CD22 and low expression of CD5 in one case (Figure 2). The immunophenotypic characteristic of leukemic cells of HCL in this study were: CD19+, CD22+, CD23+, CD25+, CD38+, strong sIg+ and CD5- (Figure 3). The leukemic cells from MCL patient were characterized by strong expression of CD5, sIg and CD22 and lack of CD23 (Figure 4).

\section{Discussion}

The CD5 surface marker has a molecular weight of 65.000 67.000 daltons and it is considered to be a pan-T cell marker, pan-thymocyte marker ${ }^{1,2,5}$. A restricted B cell expressing this marker, named B1 lymphocytes which reside in fetal primary follicles and spleen, in small numbers at periphery of the germinal centers of adult lymphonodes and tonsils ${ }^{1,3,5}$.

In pathologic conditions, CD5 was identified in large numbers of B lymphocytes in the peripheral blood of patients with rheumatoid arthritis or after allogeneic bone marrow transplantations $^{1,2}$. In B-cell malignancies, CD5 also can be detected in MCL and Burkitt lymphoma/leukemia ${ }^{1,5,11,13}$.

The B-CLL is a well-characterized mature B cell lymphoid leukemia and it is the most common type of leukemia in older adults ${ }^{10,12}$. The laboratorial criteria for the diagnosis of CLL are well stabilished and include lymphocytosis of 5.000/?L (5 x $10 \% / \mathrm{L})$ or more, fewer than $50 \%$ of prolymphocytes in peripheral blood and $30 \%$ or more of lymphocytes in the bonne marrow ${ }_{10,12}$. The distinctive immunologic properties of B-CLL are expression of weak monoclonal sIg, high affinity for binding mouse erythrocytes, CD23, and CD5 expression ${ }^{\text {1,4,7,17. }}$.

Recent reports have related the cases of variant forms of BCLL that lack CD5 expression that represent fewer than $2 \%$ of cases, but in this study, we have not observed any case of B$\mathrm{CLLCD}^{14}$.

HCL and hairy cell leukemia variant (HCL-v) are B cell disorders characterized by the presence of lymphocytes with cytoplasmatic projections. They share a B cell phenotype different from B-CLL: Strong expression of sIg, CD22 and FMC-7 and often CD5 negativity ${ }^{3}$. This immunophenotypic pattern of HCL, suggest that cells are in a more advanced maturation stage compared with B-CLL, and HCL cells are also considered activated B-cell due to their strong expression of CD25 and CD38 $8^{4,6,7,9}$.

In this study, for the differenced diagnosis between HCL and B-CLL, we observed the CD5 expression in B-CLL in associated with weak sIg and CD22 in all cases, and strong coexpression of CD25 and CD38 associated with high intensity of sIg and CD22 and lack expression of CD5 in all cases of HCL. 
Recently, CD103 has been indicated as the most reliable markers to distinguish HCL from other B-cell leukemias ${ }^{4,7}$, but in this study we do not utilize this cell marker.

$\mathrm{B}-\mathrm{PLL}$ is a rare chronic B-cell leukemia characterized by a high WBC count, splenomegaly and more than $55 \%$ prolymphocytes in peripheral blood ${ }^{7,15}$. The immunophenotype of leukemic cells from B-PLL are similar to B-CLL, both are CD19+, CD22+ and HLADR+. However, the cells from PLL exhibit strong FMC-7 and sIg and are usually CD5- or express low levels of this antigen ${ }_{4,7}$.

In this study, the elevated percentage of prolymphocytes in peripheral blood, lack of CD5 in two cases and weakness in one case, associated with a strong expression of sIg and CD22 in B-PLL, can be a differentiate diagnosis between BCLL and B-PLL.

Peripheral blood involvement in MCL is common and sometimes a diagnostic problem with respect to B-CLL may arise. Similar to B-CLL, lymphocytes from MCL are CD5+ in most of cases and in $40 \%$ they show a weak CD22 positivity $^{7,16,18}$.

However, the presence of a strong expression of sIg and lack of CD23 in MCL can distinguish MCL and B-CLL ${ }^{4,7,16,18}$.

\section{Conclusion}

In conclusion, the results of the current study demonstrated that CD5 expression can distinguish the B-CLL of other chronic B-cell malignancies such as HCL and B-PLL but not between B-CLL and MCL.

\section{References}

1. Hayakawa K, Hardy RR. Normal, autoimmune and malignant CD5+ B cells: The Ly-1 B lineage? Ann Rev Immunol. 1988; 6: 197-218.

2. Batata A, Shen B. The importance of surface immunoglobulin, mouse rosettes and CD5 in the immunophenotyping of chronic lymphocytic leukemia and reactive lymphocytosis. Cancer, 1991;68: 355-61.

3. Lavabre-Brertrand T, Janossy G, Exbrayat C, Bourquard P, Duperray C, Navarro M. Leukemia-Associated changes identified by quantitative flow cytometry. CD5 Over expression and monitoring in B-CLL. Leukemia 1994; 8:1557-63.
4. Matutes E. Contribution of immunophenotyping in the diagnosis and classification of haemopoietic malignancies. J Clin Pathol 1995; 48:194-7.

5. Thomas JK. The CD5 B cell. Adv Immunol. 1989;27: 117-185.

6. Tbakin A, Edinger M, Myles J. Flow cytometric immunophenotyping of non-Hodgkin's lymphomas and related disorders. Cytometry 1996; 25: 113-124.

7. Ginaldi L, De Martinis, M, D’Ostilio A, Francesca LM, Quaglino D. The immunophenotypic analysis of chronic lymphoid leukemias. Cancer J 1998; 11: 284-8.

8. Garand R, Robillard N. Immunophenotypic characterization of acute leukemias and chronic lymphoproliferative disorders: practical recommendations and classifications. Hematol cell ther. 1996; 38: 471-86.

9. Jennings DC, Foon KA. Recent advances in flow cytometry: aplication to the diagnosis of hematologic malignancy. Blood 1997; 90: 2863-92.

10. Rozman C, Montserrat E. Chronic lymphocytic leukemia. N Engl J Med 1995; 333:1052-6.

11. Freedman AS. Immunobiology of chronic lymphocytic leukemia. Hematol Oncol Clin North Am. 1980;4:405-29.

12. Peter Gale R, Foon KA. Biology of chronic lymphocytic leukemia. Semin Hematol 1987; 24 : 209-229.

13. Wu Lin C, O`Brien S, Faber J, Manshouri T, Romaguer AJ, Huh YO, Kantarjian H, Keating M, Albitar M. De novo CD5+ Burkitt lymphoma / leukemia. Am.J Clin Pathol. 1999; 112:828-35.

14. Huang JC, Finn WC, Goolsby CL, Variakojis D, Peterson, LC. CD5- smal B-cell leukemia are rarely classifiable as chronic lymphocytic leukemia. Am J Clin Pathol. 1999; 111:123-30.

15. Schelette E, Bueso-Ramos C, Giles, F, Glassman A, Hayes K, Medeiros J. Mature B cell leukemias with more than 55\% prolymphocytes. Am J Clin Pathol 2001: 115: 571-81.

16. Pittaluga S, Wlodarska I, Strul MSTJ, Verhoef G, Cassiman JJ, van den Berghe H, de Wolf-Peeters C. Mantle cell lymphoma: a clinicopathological study of 55 cases. Histopathology 1995; 26:17-24.

17. Sarfati, M. CD23 and chronic lymphocytic leukemia. Blood Cell 1996; 19: 591-6.

18. Garcia DP, Rooney MT, Ahmad E, Davis BH. Diagnostic usefulness of CD23 and FMC-7 antigen expression pattern in Bcell lymphoma classification. Am J Clin Pathol. 2001; 115: 258-65. 
Cavalcanti Júnior GB, Sales VSF, Silva DGKC, Lopes MCA, Paiva AS, Fonseca HEM, Nascimento Júnior FF, Fernandes MZ. Detecção do CD5 em doenças linfoproliferativas crônicas de células B por citometria de fluxo: uma importante expressão em leucemia linfocítica crônica. Acta Cir Bras [serial on line] Available from: URL: htt://www.scielo.br/acb.

RESUMO - Objetivos: CD5 é um marcador normalmente expresso nas células T e de forma aberrante nas células B da leucemia linfocítica crônica (LLC) e no linfoma de células do manto (LCM). Outras doenças linfoproliferativas crônicas como a hairy cell leukemia (HCL) e leukemia prolinfocítica de células B (LPL-B), são geralmente CD5 negativas ou expressam fracamente este antígeno. Neste trabalho investigou-se o padrão de expressão do CD5 em 42 pacientes com doenças linfoproliferativas crônicas de células B (DLC-B). Metodos: Investigamos a expressão de CD5 em células leucêmicas de 42 pacientes com DLC-B através da citometria de fluxo. Dados demográficos, tais como idade e sexo, bem como dados clínicos e laboratoriais também foram analisados. Resultados: A imunofenotipagem mostrou que 35 casos foram LLC, 3 LPL-B, 3 HCL e um caso de LMC. O CD5 mostrou-se fortemente expresso em todos os casos de LLC e LMC. Baixa expressão desse antígeno foi observada em um caso de LPL-B, mostrando-se negativamente expresso em todos os casos de HCL. Conclusão: Nossos resultados demonstram que o padrão de expressão do CD5 pode auxiliar na distinção entre LLC da HCL e LPL-B, sendo no entanto similares na HCL e LCM.

DESCRITORES: CD5. Leucemia linfocítica crônica. Células B. Linfoma. Células do manto.

Correspondence:

Prof. Geraldo Barroso Cavalcanti Júnior

Laboratório de Imunologia Clínica - DACT, UFRN

Rua General Gustavo Cordeiro de Farias S/N, Petrópolis

Natal-RN, Brasil, CEP: 59010-180

E-mail: gbcjunior@hotmail.com 